\title{
SUSPENSION SORBENTS FOR REMOVAL OF ARSENIC COMPOUNDS AND HUMATES FROM WATER
}

\author{
${ }^{1 *}$ Marta Litynska, ${ }^{1}$ Tetiana Dontsova \\ ${ }^{1}$ Department of Technology of Inorganic Substances, Water Treatment and General Chemical \\ Technology, National Technical University of Ukraine "Igor Sikorsky Kyiv Polytechnic Institute", \\ Kyiv, 03056, Ukraine.
}

*Corresponding author: m.litynska-2017@kpi.ua

\begin{abstract}
This paper is devoted to the features of the synthesis and applications of suspension iron(III)-based sorbents in water treatment. The problems of toxic impurities of the drinking water, especially soluble arsenic compounds or different organic disinfection by-products, are very acute not only for Ukraine, but for many other countries too. So, it is very important to find simple and effective method to treat polluted natural waters to the required quality. The comparison of different treatment methods for removal of arsenic compounds and humates was made, as a result of which it was determined that the usage of adsorbents, especially fine particle iron-based sorbents, is very effective in natural organic matter removal and some other pollutants. Fine particle iron-based adsorbents are effective for arsenic removal due to its chemical structure. These materials removed arsenic compounds by chemisorption processes and immobilization of arsenate and arsenite ions in the insoluble form of ferric arsenate. Thus, the aim of the work was to develop the adsorbent for effective removal of arsenic compounds and humates from natural waters. We synthesized 7 suspension iron(III)-based sorbents by homogeneous precipitation from $\mathrm{FeCl}_{3}$ solution by thermal hydrolysis of urea. The efficiency of synthesized samples was checked by adsorption tests (humates and arsenite removal) and capillary suction time test. Iron(III) oxyhydroxide was the main phase of the most effective fine particle adsorbents. Applications on natural water showed that the synthesized iron(III) oxyhydroxide effectively removed arsenic compounds not only from model waters, but also from natural water with reaching of regulatory requirements.
\end{abstract}

Key words: adsorption; arsenic removal; arsenite; humates; fine particle iron(III) oxyhydroxide; suspended sorbents. 


\section{Introduction}

Global Warming and irrational usage of water resources cause negative changes in water compositions of surface and groundwater sources. Increased water demand causes depletion of some aquifers, admixture of pure water and water from polluted aquifers and increasing of different toxic components (for example arsenic) leaching from rocks and minerals. Global Warming and high nutrients content provoke increasing of populations of water plants, algae, plankton, etc. During cold period decomposition of this biomass takes place. It results in high content of humic compounds in water bodies.

Incomplete natural organic matter (NOM) removal leads to the formation of disinfection byproducts, which are often harmful and smelly, during chlorination (Villanueva et al., 2015).

There are some modern approaches for colour removal, especially ballasted coagulation on the lamellas (Capodaglio et al., 2011), ballasted flotation (Jarvis et al., 2011), nanofiltration (Vergel et al., 2017), combination of coagulation and microfiltration (Ødegaard et al., 2010), biofiltration with pre-oxidation (Pharand et al., 2015), adsorption (Bhatnagar \& Sillanpää, 2017), ion exchange (Levchuk, Márquez \& Sillanpää, 2018), electrochemical methods (Särkkä, Vepsäläinen \& Sillanpää, 2015), etc.

Perspective solution of NOM problem is the application of membrane technology. According to (Plourde-Lescelleur et al., 2015) nanofiltration is significantly more effective in NOM removal than coagulation by aluminium or iron compounds. But using of this method is limited by fouling problem (Shan et al., 2016). Membrane fouling by NOM can't be restored only through physical scrub like backwash and air cleaning, so pretreatment process are important for long-term stable operation of a membrane (Sun et al., 2013). Combination of coagulation and microfiltration also has some disadvantages, especially clogging of membrane pores by amorphous flocs (Kim, Deng \& Benjamin, 2008). Thus, in case of natural water with high organic content usage of these methods leads to significant decreasing of work resource of membranes and high consumption of chemicals for treatment.

Adsorption is very popular for the removal of organic compounds. Modified activated carbons (Park et al., 2015) and zeolites (Mahvi et al., 2016) are often used for this purpose. Conventional adsorption filters have high physical footprint due to low filtration velocities.

Fine particle adsorbent is one of the novel methods of NOM removal. According to the previous studies system adsorbent/membrane demonstrates high NOM removal and fouling prevention efficiency (Litynska et al., 2019). Thus, fine particle iron oxyhydroxide demonstrates higher efficiency in organic removal than powdered activated carbon. 
Other important problem is increasing of content of toxic elements and heavy metals in natural waters due to changes of groundwater level and acidic rains. Arsenic is one of the most dangerous elements in world. Now the maximum allowable concentration of arsenic in drinking water is $10 \mu \mathrm{g} / \mathrm{l}$ (European Commission, 1998). High arsenic level in natural water are typical for India, Bangladesh, Taiwan, Vietnam, USA, Mexico, Argentina, Hungary, Ghana, China, Chile, Iran, etc. (Litynska, Tolstopalova \& Astrelin, 2017). Chronic arsenic exposure provokes different health problems, such as skin lesions, hyperkeratosis, melanosis, skin cancer and cancer of internal organs (Mandal \& Suzuki, 2002).

Arsenic compounds can be removed from water by different methods, especially, coagulation (Elyahyaoui et al., 2016), reverse osmosis (Abejón, Garea \& Irabien, 2015), biotreatment (Rahman et al., 2014), ion exchange (Lee et al., 2017), lime softening (Odell, 2016), adsorption (Lim \& Aris, 2014), etc. These approaches have the same disadvantages as in the case of NOM removal, especially, large physical footprint, significant consumption of chemicals and energy, etc.

Fine particle iron-based adsorbents are effective for arsenic removal due to its chemical structure. They remove arsenic compounds by chemisorption processes and immobilization of arsenate and arsenite ions in the insoluble form of ferric arsenate. So, fine particle iron-containing adsorbents can effectively remove NOM and arsenic compounds, and it also can effectively protect membranes from colloidal fouling.

Thus, the aim of the work was to develop the adsorbent for effective removal of arsenic compounds and humates from natural waters.

\section{Materials and Methods}

Adsorbent synthesis. Fine particle adsorbents were synthesized from $\mathrm{FeCl}_{3}$ solution by thermal hydrolysis of urea. Synthesis conditions (urea: $\mathrm{FeCl}_{3}$ ratio and boiling duration) were varied for different samples of sorbent materials (Table 1).

Table 1. Synthesis conditions

\begin{tabular}{|c|c|c|}
\hline Sorbent & Urea:FeCl $\mathbf{3}$ ratio & Boiling duration, min \\
\hline SFU (15/30) & $15: 1$ & 30 \\
\hline SFU (10/30) & $10: 1$ & 30 \\
\hline SFU (8/30) & $8: 1$ & 30 \\
\hline SFU (5/30) & $5: 1$ & 30 \\
\hline SFU (10/15) & $10: 1$ & 15 \\
\hline SFU (10/60) & $10: 1$ & 60 \\
\hline SFU (8/60) & $8: 1$ & 60 \\
\hline
\end{tabular}


$150 \mathrm{~g}$ of urea was dissolved in $200 \mathrm{ml}$ of distilled water and $\mathrm{FeCl}_{3}$ solution (with concentration $0.6 \mathrm{M}$ ) was added to the urea solution. The mixture was heated to the temperature about $95{ }^{\circ} \mathrm{C}$ with constant stirring and boiled at this temperature for 15, 30 or 60 minutes. The resulting suspension is cooled and rinsed by decantation using distilled water. The sorbent is stored and used as a suspension.

X-ray diffraction. X-ray diffractometer DRON-2 was used for phase determination. The experiments were made using monochromatic Co- $\mathrm{K}_{\alpha}$ radiation with the wavelength of $\lambda=1.7902 \mathrm{~A}$. The phases were identified using PCPDFWIN database.

Microscopy. Light microscopy was made by microscope Leica DM6 B. The drop of sorbent suspension was placed on microscope slide and covered by cover glass. Drop of oil was placed on the chosen place on cover glass. It enhanced quality of image and protected objective. Camera Leica DMC4500 transmited image to the computer.

CST test. The main principle of CST (Capillary Suction Time) test is filtration force generated by the capillary action of an absorbent filter paper is applied to suspension. Sorbents were diluted to the contentration $10 \mathrm{~g} / 1.5 \mathrm{ml}$ of suspension was poured into the funnel fixed on absorbent filter paper, which was placed between two plastic blocks. Capillary Suction Timer showed time, which liquid need to reach the electrode. It gave information about filtration properties of suspension.

Arsenic removal. For experiment solutions with different arsenite contents (500, 2000, 4000, 10000, 12000, $15000 \mu \mathrm{g} / \mathrm{l}$ ) were used. In Erlenmeyer flasks were poured $250 \mathrm{ml}$ of arsenite solution and were added sorbent suspension. Adsorbent dose was $50 \mathrm{mg} / \mathrm{l}$.

Humates removal. Portions $(200 \mathrm{ml})$ of model water (initial concentration of Na salt of humic acid was $5 \mathrm{mg} / \mathrm{l}$ with colour $60 \mathrm{mg} \mathrm{Pt} / \mathrm{l}$ and 0,530 UV-254, concentration of $\mathrm{NaHCO}_{3}$ was $5 \mathrm{mg} / \mathrm{l}$ ) were placed in Erlenmeyer flasks (volume of flask was $250 \mathrm{ml}$ ) with screw caps. pH was adjusted to 5.8 by $1 \mathrm{M}$ solution of $\mathrm{HCl}$. Sorbent was dosed into flasks. Sorbent doses were: 25; 50; 60; 70; 80; 90; $100 ; 110$ and $120 \mathrm{mg}$ of solid sorbent per liter. After that flasks were placed on the orbital shaker. Shaking duration was $5 \mathrm{~h}$ (equilibrium time).

Adsorbent application for natural waters. Artesian water samples from Kwasy (Western Ukraine) were used for experiments. Mixing of raw water (0.5 1) and ferric oxyhydroxide (50; 110 and $200 \mathrm{mg}$ of solid sorbent per liter) was the first stage. Second step described interaction between adsorbent particles and impurities. Arsenites and arsenates were immobilized on the particle surface due to formation of insoluble ferric arsenate. Separation was the third step. Adsorbent with immobilized impurities formed protective layer on the membrane surface. Backwash was the fourth stage. Water flow removed adsorbent with immobilized pollutants. After it membrane was as clean as before filtration. Water was mixed with ferric oxyhydroxide suspension and separated by fixed in filter holder membrane filter. Arsenic content was determinated in filtrate. Total arsenic 
concentration was detected photometrically in the form of blue compound of redoxing of heteropoly acids.

\section{Results and discussion}

Iron(III) oxyhydroxide was the main phase of two chosen for X-ray diffraction analysis fine particle adsorbents (samples SFU (8/30) and SFU (8/60)), that were synthesized from $\mathrm{FeCl}_{3}$ solution by thermal hydrolysis of urea (Fig. 1).

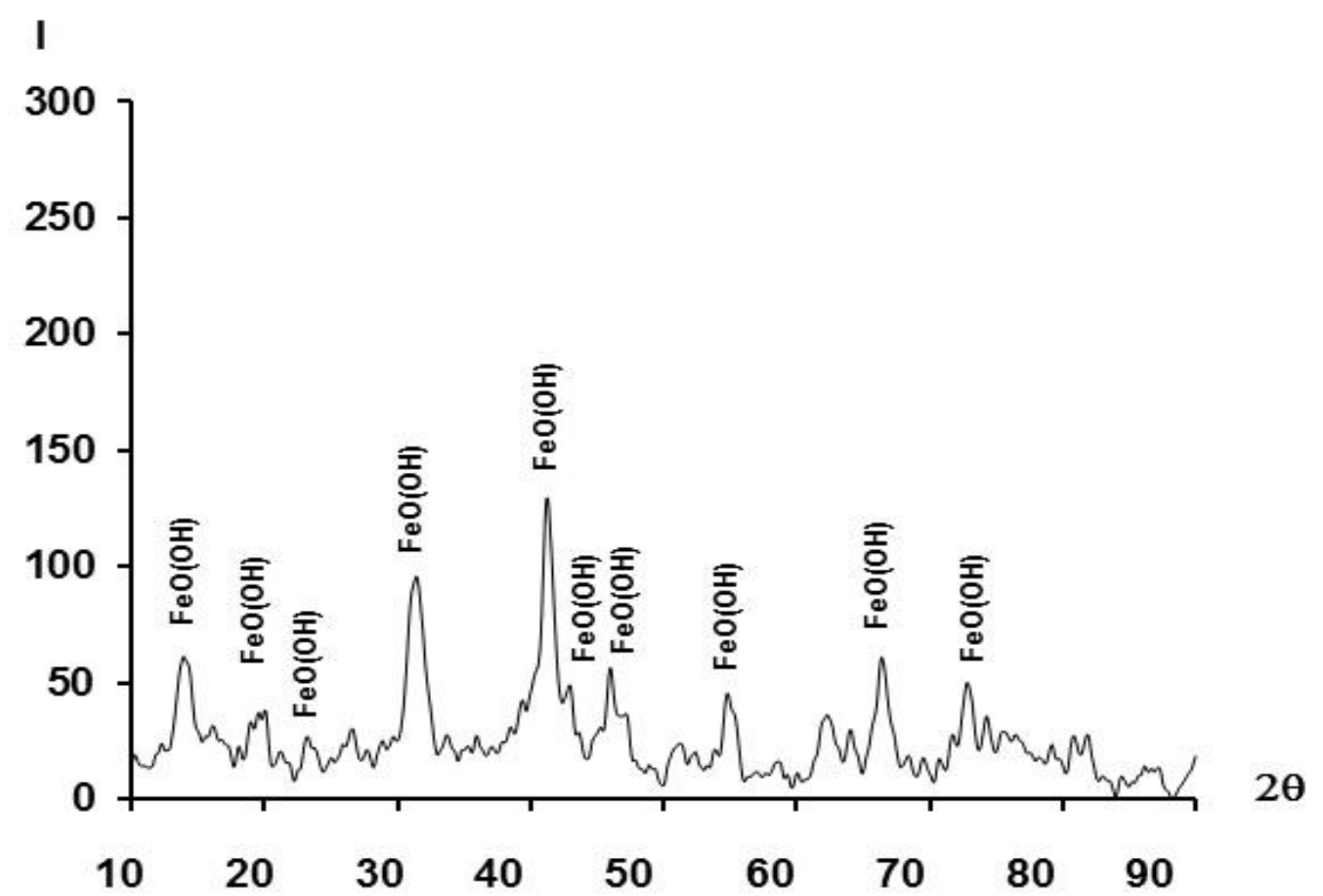

Fig. 1. X-ray diffraction of dried adsorbent (sample SFU (8/30)).

SFU (8/60) demonstrated the same X-ray diffraction results, thus its diffraction curve was not placed in this paper.

These adsorbents had spherical particles with almost the same size (Fig. 2), which is convenient for use in the sorption-membrane treatment method.

The ratio of urea to iron(III) chloride significantly affected the particle size and possibly the synthesized phase, as samples with a ratio of 15 had a brown color, which was characteristic for the amorphous hydroxide phase. The sample with a ratio of 5 (SFU (5/30)) is very fine (particles less than $1 \mu \mathrm{m})$, which is undesirable for microfiltration membranes. 


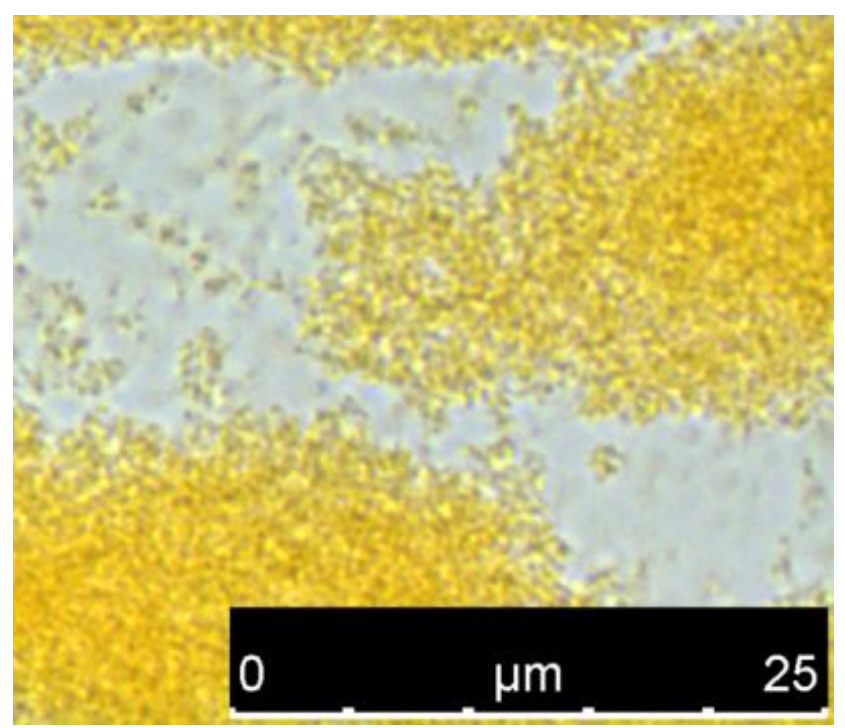

Fig. 2. Light microscopy of SFU (8/30) sample.

According to the capillary suction time (CST) test (Fig. 3), the most perspective were sorbents SFU (8/30) and SFU (8/60), which differed only in the duration of boiling (30 or 60 minutes).

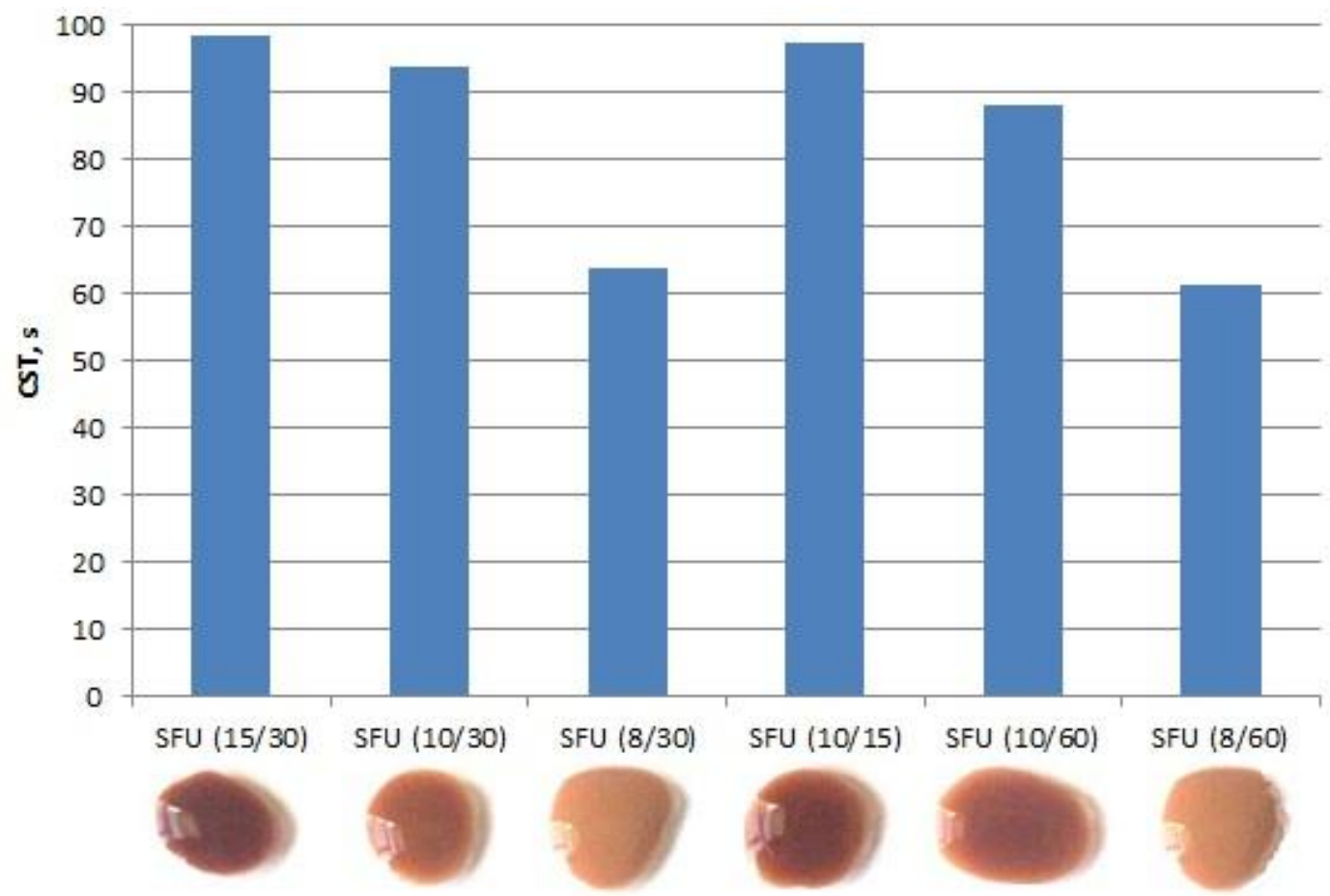

Fig. 3. CST test for adsorbents suspensions.

CST of SFU (8/30) was $63.7 \mathrm{~s}$ and CST of SFU (8/60) was $61.3 \mathrm{~s}$. Samples with major urea:FeCl $\mathrm{F}_{3}$ ratio (10-15) had higher CST (88.2-98.4 s).

Whereas SFU (8/30) and SFU (8/60) demonstrated almost the same results, in order to reduce the cost of the sorption material, it was advisable to choose boiling for only 30 minutes.

All adsorbent samples showed similar sorption properties to arsenate and arsenite ions (Fig. 4). 


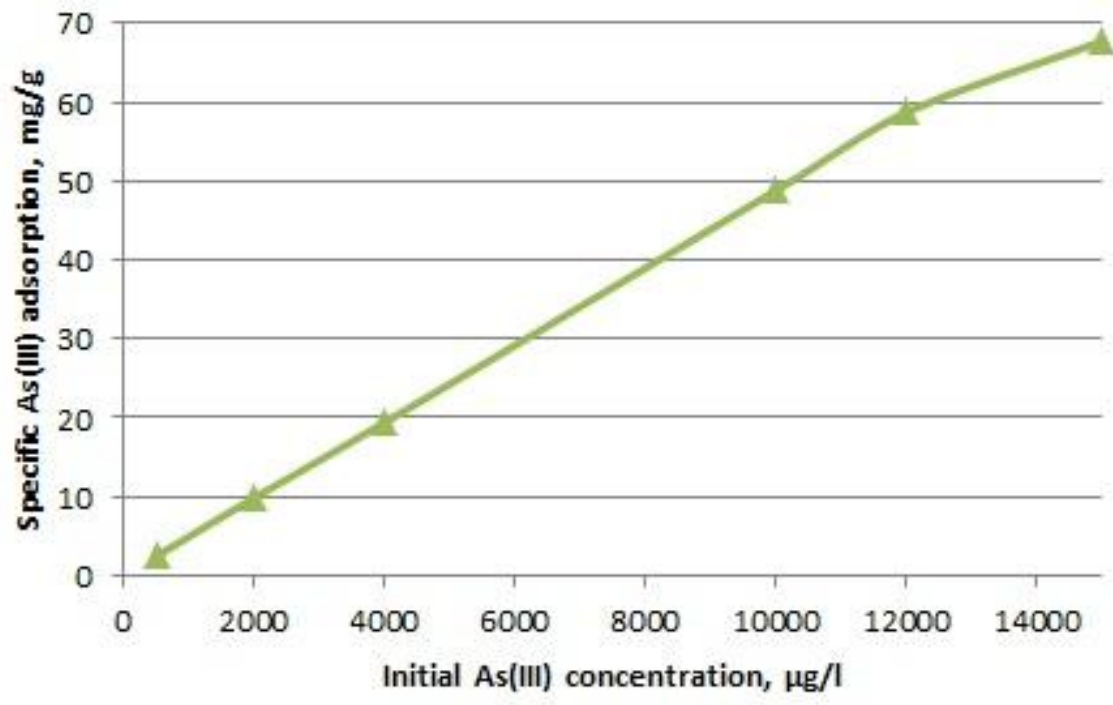

Fig. 4. Removal of arsenite from solutions (SFU (8/30)).

At high arsenic content (15000 $\mu \mathrm{g} / \mathrm{l})$ specific As(III) adsorption was high $(67.7 \mathrm{mg} / \mathrm{g})$, but residual arsenic level at this sorbent dose $(50 \mathrm{mg} / \mathrm{l})$ was significantly higher $(1463 \mu \mathrm{g} / \mathrm{l})$ than maximum allowable concentration for drinking water. Thus, dose $50 \mathrm{mg} / \mathrm{l}$ was not enough for effective treatment and it was recommended to use higher adsorbent doses for water with significant arsenic content.

Comparing the most efficient samples, we can conclude that SFU (8/30) demonstrated the best sorption efficiency for humates (Fig. 5).

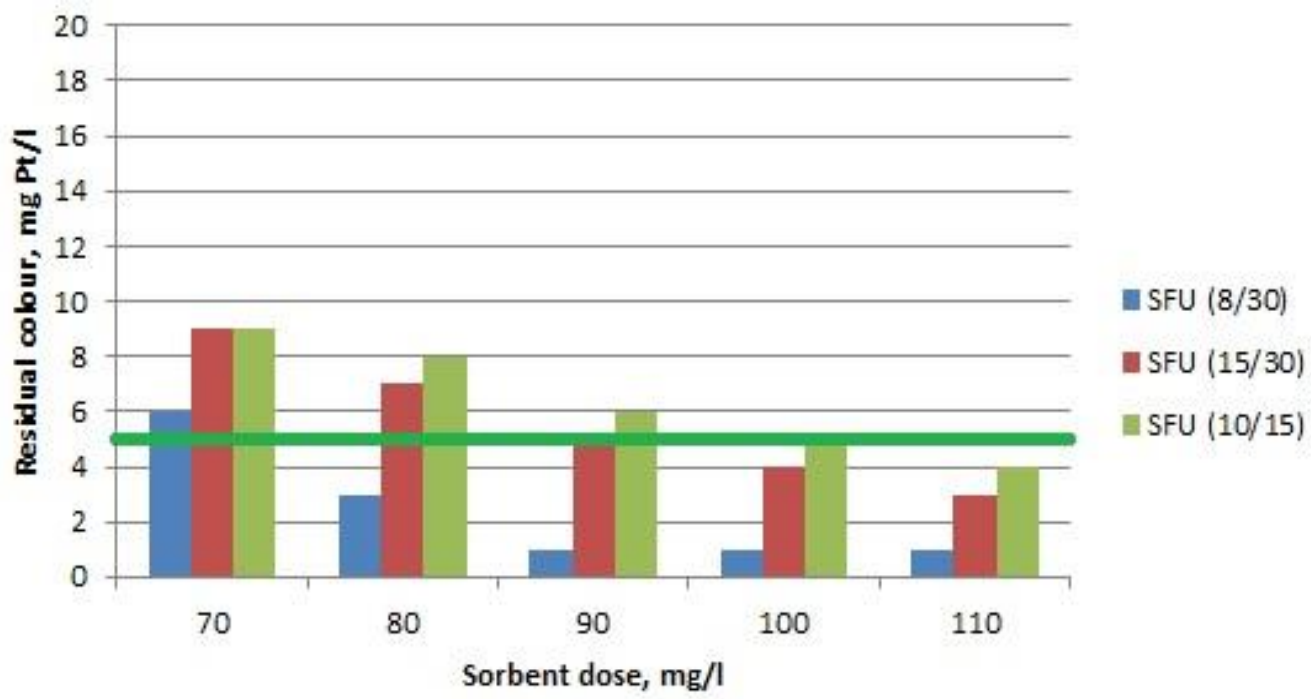

Fig. 5. Humates removal.

According to the standard for drinking water, the maximum allowable colour was $20 \mathrm{mg} \mathrm{Pt} / \mathrm{l}$, but this water had a slight yellowish tinge, which could be negatively perceived by the consumers. Therefore, it was decided to treat water to $5 \mathrm{mg} \mathrm{Pt/l}$ of residual colour, as the colour of such water was almost invisible. For SFU (8/30) $80 \mathrm{mg} / \mathrm{l}$ was enough for residual colour $3 \mathrm{mg} \mathrm{Pt} / \mathrm{l}$, but for 
effective humates removal by SFU (15/30) and SFU (10/15) were required higher doses (90 and $100 \mathrm{mg} / \mathrm{l}$, respectively).

In Ukraine, groundwater with the highest arsenic content was located in the area of Rakhiv-Tysa deep transverse fault due to the release of arsenic-containing rocks from deep layers.

Two samples taken near village Kwasy (Western Ukraine). These waters had very high contents of arsenic (16733 and $13263 \mu \mathrm{g} / \mathrm{l})$. It was more than in 1673 and 1326 times, respectively, exceeds the maximum permissible concentration of arsenic in drinking water (Table 2).

Table 2. Check the synthesized adsorbent on the samples of natural water

\begin{tabular}{|c|c|c|c|c|c|}
\hline \multicolumn{3}{|c|}{ Sample 1 } & \multicolumn{3}{c|}{ Sample 2 } \\
\hline Dose, mg/l & As content, $\boldsymbol{\mu g} / \mathbf{l}$ & $\mathbf{p H}$ & Dose, mg/l & As content, $\boldsymbol{\mu g} / \mathbf{l}$ & $\mathbf{p H}$ \\
\hline Raw water & 16733 & 6.46 & Raw water & 13263 & 6.02 \\
\hline 50 & 3133 & 7.70 & 50 & 2825 & 7.16 \\
\hline 110 & 1067 & 8.15 & 110 & 803 & 7.65 \\
\hline 200 & $5>$ & 8.42 & 200 & $5>$ & 8.03 \\
\hline
\end{tabular}

Low dosages (50 and $110 \mathrm{mg} / \mathrm{l}$ ) demonstrated insufficient efficiency of arsenic removal. But the dose of $200 \mathrm{mg} / \mathrm{l}$ of the sorbent SFU (8/30) could treat water to the safe quality (arsenic concentrations after treatment were lower than $10 \mu \mathrm{g} / \mathrm{l})$.

\section{Conclusions}

Studies on the sorption removal of arsenic and humate compounds by synthesized adsorbents demonstrated that adsorbents, synthesized from $\mathrm{FeCl}_{3}$ solution by thermal hydrolysis of urea, were very perspective for arsenic compounds and humates removal from water. Based on the $\mathrm{FeOOH}$ phase samples had high specific adsorption of arsenate and arsenite ions (about $70 \mathrm{mg} \mathrm{As/g}$ ), short capillary suction time (61.3-63.7s) and higher than other synthesized materials, sorption efficiency against humates. Thus, the synthesized iron(III) oxyhydroxide effectively removed arsenic compounds of various origins (arsenates, arsenites and humic substances).

Tests on natural water showed that the synthesized iron(III) oxyhydroxide effectively removed arsenic compounds not only from model waters, but also from natural water with reaching of regulatory requirements.

\section{Conflict of interests}

The authors declare that they have no conflict of interest. 


\section{References}

Abejón, A.; Garea, A.; Irabien, A. "Arsenic removal from drinking water by reverse osmosis: Minimization of costs and energy consumption". Separation and Purification Technology, 2015, 144, 46-53. http://doi.org/10.1016/j.seppur.2015.02.017.

Bhatnagar, A.; Sillanpää, M. "Removal of natural organic matter (NOM) and its constituents from water by adsorption - A review". Chemosphere, 2017, 166, 497-510. https://doi.org/10.1016/j.chemosphere.2016.09.098

Capodaglio, A. G.; Callegari, A.; Sauvignet, P. "Advanced separation technology application for NOM removal from a freshwater supply". In IWA Spy Conference on Natural Organic Matter, Costa Mesa, CA, USA, 2011, 1-11.

Elyahyaoui, A.; Razzouki, B.; Ellouzi, K.; Hajjaji, M.; Bouhlassa, S.; Azzaoui, K. "Arsenic coagulation / flocculation with iron (III) hydroxide: Adsorption mechanisms and stability constants of surface". International Journal of Development Research, 2016, 6(11), 10013-10018.

European Commission Council Directive 98/83/EC, 1998, 31(November 1998), 1-32. http://doi.org/2004R0726 - v.7 of 05.06.2013.

Jarvis, P.; Martin, J.; Winspear, T.; Jefferson, B. "Ballasted flotation with glass microspheres for removal of natural organic matter". Separation Science and Technology, 2011, 46(16), 2489-2495. https://doi.org/10.1080/01496395.2011.607484

Kim, J.; Deng, Q.; Benjamin, M. M. "Simultaneous removal of phosphorus and foulants in a hybrid coagulation/membrane filtration system". Water Research, 2008, 42(8-9), 2017-2024. http://doi.org/10.1016/j.watres.2007.12.017.

Lee, C. G.; Alvarez, P. J. J.; Nam, A.; Park, S. J.; Do, T.; Choi, U. S.; Lee, S. H. "Arsenic(V) removal using an amine-doped acrylic ion exchange fiber: Kinetic, equilibrium, and regeneration studies". Journal of Hazardous Materials, 2017, 325, 223-229.

http://doi.org/10.1016/j.jhazmat.2016.12.003.

Levchuk, I.; Márquez, J. J. R.; Sillanpää, M. "Removal of natural organic matter (NOM) from water by ion exchange - A review". Chemosphere, 2018, 192, 90-104. https://doi.org/10.1016/j.chemosphere.2017.10.101

Lim, A. P.; Aris, A. Z. "A review on economically adsorbents on heavy metals removal in water and wastewater". Reviews in Environmental Science and Biotechnology, 2014, 13(2), 163-181. http://doi.org/10.1007/s11157-013-9330-2.

Litynska, M.; Antoniuk, R.; Tolstopalova, N.; Astrelin I. "Ferric Oxyhydroxide as Fouling Prevention Reagent for Low-Pressure Membranes". J. Ecol. Eng., 2019, 20(3), 77-84. https://doi.org/10.12911/22998993/99736 
Litynska, M.; Tolstopalova, N.; Astrelin, I. "Neutralization of arsenic pollutants, contained in natural waters: The theoretical analysis of solubility of some arsenates and optimization of the processes". J. Water Environ. Nanotechnol., 2017, 2(21), 1-81.

http://doi.org/10.7508/jwent.2017.01.001.

Mahvi, A. H.; Vosoughi, M.; Mohammadi, M. J.; Asadi, A.; Hashemzadeh, B.; Zahedi, A.; Pourfadakar, S. "Sodium Dodecyl Sulfate Modified-Zeolite as a Promising Adsorbent for the Removal of Natural Organic Matter From Aqueous Environments". Health Scope, 2016, 5(1), 1-8. http://doi.org/10.17795/jhealthscope-29966.

Mandal, B. K.; Suzuki, K. T. "Arsenic round the world: A review". Talanta, 2002, 58(1), 201-235. http://doi.org/10.1016/S0039-9140(02)00268-0.

Ødegaard, H.; Østerhus, S.; Melin, E.; Eikebrokk, B. "NOM removal technologies - Norwegian experiences". Drink. Water Eng. Sci, 2010, 3, 1-9. http://doi.org/10.5194/dwesd-2-161-2009.

Odell, L. H. "Cut Drinking Water Arsenic Levels Using Best Removal Strategies". Opflow, 2016, 42, 26-30. http://doi.org/10.5991/OPF.2016.42.0035.

Park, H.-S.; Koduru, J. R.; Choo, K.-H.; Lee, B. "Activated carbons impregnated with iron oxide nanoparticles for enhanced removal of bisphenol A and natural organic matter". Journal of Hazardous Materials, 2015, 286, 315-324. http://doi.org/10.1016/j.jhazmat.2014.11.012.

Pharand, L.; Van Dyke, M.; Anderson, W. B.; Yohannes, Y.; Huck, P. M. "Full-Scale Ozone Biofiltration: Seasonally Related Effects on NOM Removal". Journal of American Water Works Association, 2015, 107(8), 425-435. http://doi.org/10.5942/jawwa.2015.107.0121

Plourde-Lescelleur, F.; Papineau, I.; Carrière, A.; Barbeau, B.; Gadbois, A. "NOM removal: evaluating five process alternatives to alum coagulation". Journal of Water Supply: Research and Technology, 2015, 1, 278-289. http://doi.org/10.2166/aqua.2014.090.

Rahman, S.; Kim, K. H.; Saha, S. K.; Swaraz, A. M.; Paul, D. K. "Review of remediation techniques for arsenic (As) contamination: A novel approach utilizing bio-organisms". Journal of Environmental Management, 2014, 134, 175-185. http://doi.org/10.1016/j.jenvman.2013.12.027.

Särkkä, H.; Vepsäläinen, M.; Sillanpää, M. "Natural organic matter (NOM) removal by electrochemical methods - A review". Journal of Electroanalytical Chemistry, 2015, 755, 100108. https://doi.org/10.1016/j.jelechem.2015.07.029

Shan, L.; Fan, H.; Guo, H.; Ji, S.; Zhang, G. "Natural organic matter fouling behaviors on superwetting nanofiltration membranes". Water Research, 2016, 93, 121-132. http://doi.org/10.1016/j.watres.2016.01.054.

Sun, W.; Liu, J.; Chu, H.; Dong, B. "Pretreatment and membrane hydrophilic modification to reduce membrane fouling". Membranes, 2013, 3(3), 226-241. http://doi.org/10.3390/membranes3030226. 
Vergel, C.; Franks, R. N.; Bartels, C.; Neculau, M. "A nanofiltration membrane for the removal of color from surface water to meet Norwegian standards". Desalination and Water Treatment, 2017, 85, 6-15. http://doi.org/10.5004/dwt.2017.21230.

Villanueva, C. M.; Cordier, S.; Font-Ribera, L.; Salas, L. A.; Levallois, P. "Overview of Disinfection By-products and Associated Health Effects". Current Environmental Health Reports, 2015, 2, 107-115. http://doi.org/10.1007/s40572-014-0032-x.

\title{
СУСПЕНЗЙНІ СОРБЕНТИ ДЛЯ ВИДАЛЕННЯ СПОЛУК АРСЕНУ ТА ГУМАТІВ 3 ВОДИ
}

\author{
${ }^{1 *}$ M. І. Літинська, ${ }^{1}$ T. А. Донцзова \\ ${ }^{1}$ Кафедра технології неорганічних речовин, водоочищення та загальної хімічної технології, \\ Національний технічний університет України «Київський політехнічний інститут імені Ігоря \\ Сікорського», Київ, 03056, Україна.
}

*Автор для листування: m.litynska-2017@kpi.ua

\section{Реферат}

Дана стаття присвячена особливостям синтезу та застосування у водоочищенні суспензійних сорбентів на основі феруму(III). Присутність у питній воді токсичних домішок, особливо розчинних сполук арсену або різних органічних побічних продуктів дезінфекції, є значною проблемою не лише для України, але і для багатьох інших країн. Отже, пошук простого та ефективного методу очищення забруднених природних вод до необхідної нормативної якості $€$ досить важливим та актуальним завданням. В статті здійснено порівняння різних методів водоочищення, призначених для видалення сполук арсену та гумітів 3 водного середовища, в результаті чого було встановлено, що використання адсорбентів, особливо дрібнодисперсних сорбентів на основі феруму, демонструє високі результати при очищенні вод від природних органічних речовин та деяких інших забрудників. Дрібнодисперсні ферумвмісні адсорбенти можуть ефективно видаляти сполуки арсену завдяки своїй хімічній структурі, тобто відбувається хемосорбція та іммобілізація арсенат- та арсеніт-іонів у вигляді нерозчинного ферум(III) арсенату. Таким чином, метою роботи було розробити адсорбент для ефективного 
видалення сполук арсену та гуматів 3 природних вод. Було синтезовано 7 суспензійних сорбентів на основі феруму(III) шляхом гомогенного осадження з розчину $\mathrm{FeCl}_{3}$ термічним гідролізом карбаміду. Ефективність синтезованих зразків було перевірено адсорбційними експериментами (видалення гуматів та арсеніту) та визначенням часу капілярного просочування для одержаних суспензій. Було встановлено, що основною фазою найбільш перспективних суспензійних адсорбентів був ферум(III) оксигідроксид. Подальшою перевіркою адсорбенту на зразках природних вод було доведено, що синтезований ферум(III) оксигідроксид ефективно видаляє сполуки арсену не тільки 3 модельних розчинів, а й 3 природних вод, дозволяючи досягнути нормативних вимог.

Ключові слова: адсорбиія; арсеніти; видалення арсену; гумати; дрібнодисперсний ферум(III) оксигідроксид; суспензійні сорбенти. 